\title{
SEMINAR DAN WORKSHOP PEMENUHAN KEBUTUHAN SPIRITUAL PASIEN MENJELANG AJAL DAN PENGURUSAN JENAZAH
}

\author{
Murtiningsih \\ Program Studi Profesi Ners, STIKes Jayakarta \\ Email: murtiningsihkadun@gmail.com
}

\begin{abstract}
Fullfill The Spiritual Needs Of Patients End Of Life Is Important So That Patients Can Die Peacefully. Actually Not All Muslim Patients Can Be Fulfilled Spiritual Needs Because Of Lack Of Knowledge In Spiritual Needs When Sick. Management Of Sick Patients Is Done When S Ick, End Of Life And After Death. When A Muslim Dies, A Person Who Takes Care Of The Mortal Management Is Needed. Mortal Management In The Great Lenteng Region Is Carried Out By A Team From Several Related Foundations In The Lenteng Agung Region, But Due To Limited Personnel So Sometimes Residents Have Difficulty Getting People To Mortal Management. Community Service Activities Were Carried Out On 31 December 2017 In The Hall Of Rw 10 Lenteng Agung, South Jakarta With 67 Participants Of Residents Of Rw 10 And Rw 08 Lenteng Agung. This Activity Consisted Of Seminars And Workshops For Patient Guidance Patient End Of Life And The Mortal Management. The Outcome Of This Activity Was The Formation Of A Team In The Lenteng Agung Community Area In South Jakarta. A Few Days After The Seminar Workshop There Were Residents Of Rt 014 Rw 08 Lenteng Agung Who Had Pass Away And Were Taken Care Of Mortal Management Team (4 People) Who Had Participated In Community Service Seminars And Workshop On Team.
\end{abstract}

Keywords:end Of Life, mortal Management, spiritual

\begin{abstract}
ABSTRAK
Pemenuhan Kebutuhan Spiritual Pada Pasien Menjelang Ajal Penting Agar Pasien Dapat Meninggal Dengan Damai. Pada Kenyataannya Belum Semua Pasien Muslim Dapat Terpenuhi Kebutuhan Spiritualnya Karena Kurang Pengetahuan Dalam Memenuhi Kebutuhan Spiritual Saat Sakit. Pengurusan Pasien Yang Sakit Dilakukan Ketika Sakit, Menjelang Ajal Dan Setelah Meninggal. Ketika Seorang Muslim Meninggal Diperlukan Orang Yang Mengurus Jenazah. Pengurusan Jenazah Di Wilayah Lenteng Agung Dilakukan Oleh Tim Dari Beberapa Yayasan Terkait Yang Ada Di Wilayah Lenteng Agung, Akan Tetapi Karena Keterbatasan Tenaga Sehingga Terkadang Warga Kesulitan Untuk Mendapatkan Orang Yang Mengurus Jenazah. Kegiatan Pengabdian Masyarakat Telah Dilaksanakan Pada 31 Desember 2017 Di Aula Rw 10 Lenteng Agung Jakarta Selatan Dengan 67 Peserta Warga Rw 10 Dan Rw 08 Lenteng Agung. Kegiatan Ini Terdiri Dari Seminar Dan Workshop Bimbingan Pasien Menjelang Ajal Dan Pengurusan Jenazah. Luaran Dari Kegiatan Ini Terbentuknya Tim Pengurusan Jenazah Di Lingkungan Masyarakat Lenteng Agung Jakarta Selatan. Beberapa Hari Setelah Seminar Workshop Ada Warga Rt 014 Rw 08 Lenteng Agung Yang Meninggal Dan Telah Diuruskan Oleh Tim Pengurusan Jenazah (4 Orang) Yang Telah Mengikuti Kegiatan Pengabdian Kepada Masayarakat Seminar Dan Workshop Pengurusan Jenazah.
\end{abstract}

Kata Kunci: menjelang ajal, pengurusan jenazah, spiritual

PENDAHULUAN

Pada tahun akademik 2016/2017 STIKes Jayakarta memasukkan kurikulum baru keperawatan Islami sesuai dengan visi yayasan PKP DKI Jakarta.Dalam kurikulum tersebut terdapat materi 
perawatan menjelang ajal dan pengurusan jenazah. Materi tersebut diperlukan juga oleh masyarakat. Kegiatan pengabdian kepada masyarakat pada kesempatan ini memilih kegiatan seminar dan workshop pemenuhan kebutuhan spiritual pasien dan pengurusan jenazah. Kegiatan tersebut sebagai bentuk aplikasi dari keperawatan Islami yang diajarkan di kampus. Kegiatan pengabdian kepada masyarakat ini dilaksanakan untuk memenuhi kebutuhan masyarakat akan pengetahuan dan ketrampilan pemenuhan kebutuhan spiritual pasien dan pengurusan jenazah.

Spiritual menurut kamus besar Bahasa Indonesia adalah sesuatu yang berhubungan dengan atau bersifat kejiwaan, rohani, bathin (KBBI). Perawat dalam merawat perlu secara holistik memandang pasien (Kozier, 2008) yaitu bio, psiko, sosio, spiritual. Kebutuhan spiritual perlu diperhatikan dalam merawat individu yang sakit. Pada perawatan pasien yang sakit yang diperlukan adalah pengetahuan dan ketrampilan merawat orang sakit, perawatan menjelang ajal dan pengurusan jenazah ketika telah meninggal dunia.

Pada saat menjelang ajal kewajiban seorang Muslim adalah mendampingi pasien dengan talqin.Salah satu indikator mutu wajib syariah menurut Pedoman Pelayanan Standar Minimal Rumah Sakit syariah adalah pasien sakaratul maut terdampingi dengan Talqin. (MUKISI, 2017).

Pengurusan jenazah meliputi memandikan, mengkafani, menyolatkan dan menguburkan (JAKIM, 2012). Pada kegiatan seminar dan workshop pemenuhan kebutuhan spirituah menjelang ajal dan pengurusan jenazah peserta diberikan pengetahuan dan ketrampilan tentang bimbingan spiritual dan pengurusan jenazah.

\section{TARGET DAN LUARAN}

\section{Target}

Target dalam kegiatan pengabdian kepada masyarakat ini adalah:

a. Masyarakat warga RW 08 dan RW 10 Lenteng Agung, Jagakarsa, Jakarta Selatan

b. Warga yang mempunyai minat dalam menguruskan jenazah

\section{Luaran}

a. Pemahaman warga tentang bimbingan menjelang ajal dan pengurusan jenazah.

b. Terbentuknya group Whatsap untuk koordinasi pengurusan jenazah

c. Ketrampilan pengurusan jenazah

\section{METODE PELAKSANAAN}

1. Waktu dan Tempat Kegiatan

Kegiatan ini dilaksanakan pada Hari Minggu, 31 Desember 2017 pukul 08.00 - 12.00 WIB di Aula RW 10 Lenteng Agung Jagakarsa Jakarta Selatan

2. Tujuan

a. Peserta dapat memahami bimbingan menjelang ajal pada pasien penyakit terminal dan pengurusan jenazah

b. Peserta dapat mendemonstrasikan bimbingan menjelang ajal dan pengurusan jenazah

c. Terentuknya tim pengurusan jenazah di wilayah Lenteng Agung

3. Sasaran

Sasaran dalam kegiatan ini adalah warga RW 08 dan RW 10. Total sasaran adalah 67 orang.

4. Kontribusi peserta

a. Menjadi peserta kegiatan pengabdian kepada masyarakat

b. Menjadi Tim pengurusan jenazah di wilayah RW 08 dan RW 10

5. Pelaksanaan kegiatan Pengabdian Kepada Masyarakat 


\section{Kegiatan Awal}

a. Menyusun proposal kegiatan pengabdian kepada masyarakat

b. Menyiapkan materi presentasi bimbingan akhir hayat dan pengurusan jenazah

c. Menyiapkan peralatan untuk pengurusan jenazah

\section{Pelaksanaan Kegiatan}

Kegiatan pengabdian kepada masyarakat ini dilaksanakan selama 1 (satu) hari dimulai dengan tahapan sebagai berikut:

a. Persiapan,

Persiapan kegiatan pengabdian masyarakatini adalah sebagai berikut:

1) Melakukan rapat koordinasi dalam kepanitiaan dengan warga RW 10 Lenteng Agung.

2) Melakukan koordinasi antara civitas akademika yang melakukan pengabdian masyarakat.

3) Membuat surat permohonan kepada ketua RW 10 Lenteng Agung untuk pelaksanaan kegiatan pengabdian kepada masyarakat

4) Meninjau lokasi kegiatan yaitu Aula RW 10 Lenteng Agung

5) Membagi tugas pendaftaran, konsumsi, perlengkapan dan dokumentasi.

6) Menata ruangan yang akan digunakan untuk pelaksanaan pengabdian kepada masyarakat.

b. Pelaksanaan

Pelaksanaan kegiatan pengabdian kepada masyarakattelah dilaksanankan pada tanggal 31 Desember 2017 bertempat di Aula RW 10 Lenteng Agung Jagakarsa Jakarta Selatan dengan rincian pelaksanaan sebagai berikut:

1) Dilakukan koordinasi singkat pada hari $\mathrm{H}$ dengan anggota tim dan masyarakat yang ikut serta dalam kegiatan pengabdian kepada masyarakatini.

2) Pendaftaraan dibuka mulai jam 07.30

3) Saat pendaftaran peserta mendapatkan makalah dan snack

4) Peserta tidak dikenakan biaya untuk mengikuti seminar dan workshop

5) Pembukaan acara dimulai pada jam 08.00 dibuka ole pembawa acara, selanjutnya sambutan Bapak Ketua RW dan Ketua Masjid, dan sambutan tokoh masyarakat.

6) Pelaksanaan kegiatan terjadwal mulai jam 08.00-12.00, dan pelaksanaannya sesuai yang dijadwalkan.

7) Kegiatan dimulai dengan teori bimbingan akhir hayat dan pengurusan jenazah, dilanjutkan dengan praktek menyiapkan kain kafan, mengukur kain kafan, memandikan dan teknik mengkafankan jenazah.

6. Evaluasi kegiatan.

a. Rencana kegiatan pengabdian masyarakat pada kesempatan ini dilakukan di luar kampus STIKes Jayakarta

b. Pendanaan dari STIKes Jayakarta dan kerjasama dengan masyarakat RW 10

c. Masyarakat datang lebih awal yaitu jam 07.00 WIB, sehingga saat menyiapkan ruangan, panitia juga melayani pendaftaran.

d. Peserta tidak hanya dari warga RW 10 dan RW 08

e. Pada saat pelaksanaan peserta yang hadir 67 orang, masyarakat lain ada yang ingin juga untuk mengikuti acara dipersilahkan tapi tidak mendapatkan makalah karena melebihi alokasi kuota yang direncanakan. 
f. Peserta tidak hanya ibu-ibu, tetapi bapak-bapak juga mengikuti kegitan tersebut

g. Masyarakat merasa beruntung dapat mengikuti kegiatan tersebut dan memberikan saran untuk diadakan juga pada wilayah lainnya untuk warga yang belum berkesempatan mengikuti kegiatan saat ini.

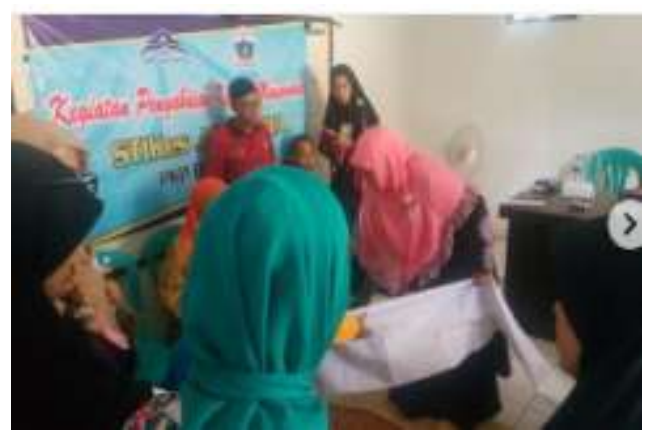

Gambar 1. Demontrasi

Menyiapkan kafan

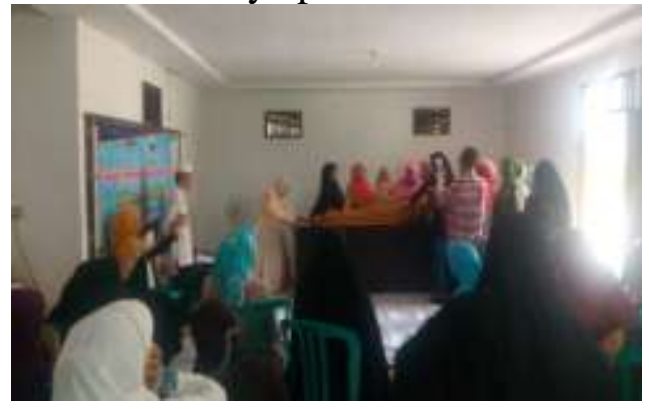

Gambar 2. Demonstarsi memandikan jenazah

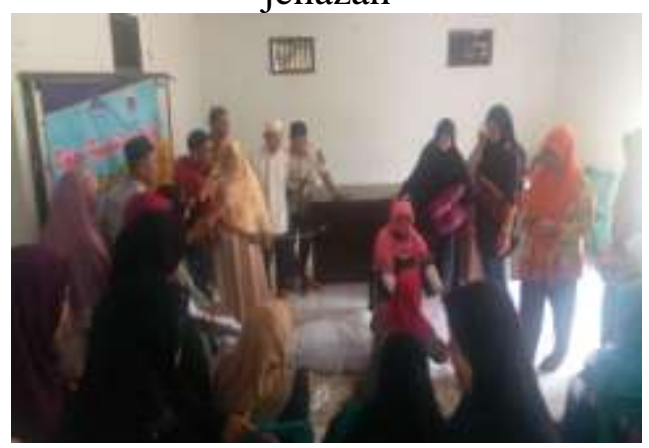

Gambar 3. Demonstrasi mengkafankan jenazah

\section{HASIL DAN PEMBAHASAN}

Metode yang digunakan dalam kegiatan ini adalah metode ceramah dan demonstrasi. Demonstarasi. Setelah kegiatan workshop pengurusan jenazah telah terbentuk group whatsapp yaitu group Majlis Ta'lim Arrohmah. Pada bulan januari ibunda salah seorang warga RT 14 Rw 08 ada yang meninggal dunia. Keluarga mengajukan permohonan kepada pembicara yaitu ibu Murtiningsih untuk pengurusan jenazah. $\mathrm{Bu}$ Murtiningsih bersedia untuk menguruskan jenazah, dan mohon kepada keluarga untuk magang peserta pelatihan membantu pengurusan jenazah. Setelah mendapatkan izin dari keluarga maka bu Murtiningsih mengumumkan dalam group WA siapa yang bersedia untuk menguruskan jenazah dapat hadir di rumah keluarga almarhumah. Peserta pelatihan yang ikut magang pengurusan jenazah sebanyak 4 orang.

Sebelum diadakan seminar dan workshop bimbingan akhir hayat dan pengurusan jenazah di wilayah RW 08 hanya ada seorang ustazah yang menguruskan jenazah, karena kurangnya pengetahuan masyarakat tentang cara pengurusan jenazah secara paktikalnya. Diantara kekurangtahuan masyarakat tentang pengurusan jenazah adalah karena kurangnya pakar dalam pengurusan jenazah, sehingga pelatihan ketrampilan pengurusan jenazah bagi masyarakat sangat dibutuhkan. (Ubaidillah, Janaka, Jurnal, \& 2018, 2018).

Peserta yang ikut magang mengurus jenazah merasakan manfaat dari pelatihan pengurusan jenazah yang telah diberikan. Kegiatan pelatihan pengurusan jenazah dirasakan manfaatnya oleh masyarakat. Hal tersebut sesuai dengan hasil kegiatan pengabdian kepada masyarakat yang telah dilakukan sebelumnya bahwa

Kegiatan pelatihan pemulasaraan jenazah memberikan dampak kepada masyarakat tidak merasa takut dalam menguruskan jenazah (Riyadi, 2013). 


\section{KESIMPULAN DAN SARAN}

1. Kesimpulan

a.Peserta yang mengikuti kegiatan pengabdian kepada masyarakat pemenuhan kebutuhan spiritual dan pengurusan jenazah sebanyak 67 orang sangat antusias mengikuti kegiatan.

b.Peserta yang telah mempraktekkan langsung pengurusan jenazah sebanyak 4 orang

c. Terbentuknya group whatsap untuk koordinasi kegiatan pengurusan jenazah.

\section{Saran}

a. Perlu dilakukannya follow up terus menerus terhadap peserta pelatihan dan magang untuk meningkatkan ketrampilan.

b. Dilakukan pelatihan pada wilayah lainnya.

\section{UCAPAN TERIMAKASIH}

Tim Pengabdian Kepada Masyarakat mengucapkan terimakasih kepada STIKes Jayakarta yang telah membantu dana dan administrasi surat izin, sehingga terlaksananya kegiatan Pengabdian Kepada Masayarakat. Serta ketua RW 10 yang telah menyediakan tempat, kepanitiaan dan sarana yang menunjang kegiatan ini dan juga kepada warga RW 08 dan RW 10.

\section{DAFTAR PUSTAKA}

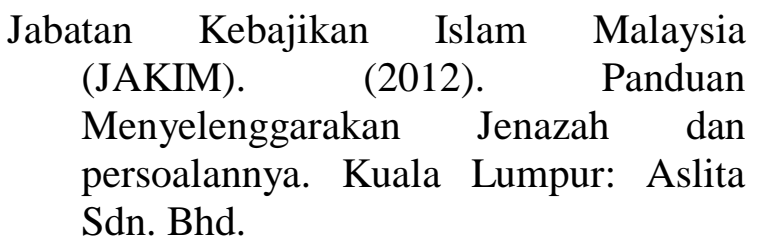

Kamus Besar Bahasa Indonesia. https://kbbi.web.id/spiritual

Kozier, B \& Erb's. (2008). Fundamentals of Nursing $8^{\text {th }}$ ed. New Jersey: Pearson.
Majelis Upaya Kesehatan Islam Seluruh Indonesia (MUKISI). (2017). Pedoman Standar Pelayanan Minimal Rumah Sakit Syariah dan Indikator Mutu Wajib Syariah. Jakarta: MUKISI.

Riyadi, A. (2013). KETERAMPILAN PEMULASARAAN JENAZAH Di Wilayah Kecamatan Mijen Kota Semarang, 13(2).

Ubaidillah, M., Janaka, N. R.-, Jurnal, undefined, \& 2018, undefined. (2018). Pelatihan Ketrampilan Pengurusan Jenazah Perempuan Melalui Metode Simulasi Peer Teaching Bagi Ibu-Ibu Fatayat Senjayan Gondang Nganjuk. Ejournal.Staida-Krempyang.Ac.Id, 8186, 59-67. Retrieved from http://ejournal.staidakrempyang.ac.id/index.php/janaka/arti cle/view/123 